Jurnal Ilmu Dan Teknologi Kesehatan

Vol 6, No 1, September 2018,

ISSN: 2338-9095 (Print)

ISSN: 2338-9109 (online)

\title{
Biskuit "Fishbean" sebagai Alternatif MP-ASI Lokal Tinggi Protein dan Vitamin A
}

\author{
Emy Yuliantini ${ }^{1}$, Kamsiah $^{2}$, Meriwati $^{3}$ \\ Politeknik Kesehatan Kementerian Kesehatan Bengkulu \\ emyardi08@yahoo.com
}

\begin{abstract}
Artikel history
Dikirim, Jun $20^{\text {th }}, 2018$

Ditinjau, Aug $20^{\text {th }}, 2018$

Diterima, Aug $27^{\text {th }}, 2018$
\end{abstract}

\section{ABSTRACT}

Less energy protein (PEM) and vitamin A deficiency have a close relationship. PEM in children can lead to a deficiency of vitamin $A$ because it can lead to inhibition of absorption, transport, and the conversion of vitamin A. One of the local food sources of protein that can be used as a complementary feeding biscuits are catfish and red beans (Pangasius spp). This study aims to analyze the contribution of complementary feeding baby biscuit with substitution catfish and red beans on the adequacy of protein and vitamin $A$ in infants. This research is purely experimental and quasi using a randomized block design (RBD) were performed with a preliminary study fishebean biscuit formulation development and the value of the nutrient content in the laboratory of Food Technology Ministry of Health polytechnic Bengkulu. The population is infants and toddlers in PHC Banyan Kingdom as the case group and control group Lempuing health centers. Total sample of 30 people, the sampling method Non-Probability Sampling. Data were collected by questionnaire respondents, organoleptic test form, and food recall intake for 3 days. Data were analyzed by one-way ANOVA and the average difference test by the independent method sample t-test. The result showed no difference in the intake of protein and vitamin $A$ in the treatment group (fed babies biscuit fishbean) and control groups (infants fed biscuit pabrikkan). There are differences in the intake of protein and vitamin $A$ between the control group with the cases at an average contribution of the adequacy of protein biscuit fishbean baby was 19.60 grams .

Keywords: Biscuit FishBean, Protein, Vitamin A

\begin{abstract}
ABSTRAK
Kurang energy protein (KEP) dan defisiensi vitamin A memiliki hubungan yang erat. KEP pada balita dapat menimbulkan defisiensi vitamin A karena dapat mengakibatkan terhambatnya absorbs, transportasi, dan konversi vitamin A. Salah satu bahan pangan lokal sumber protein yang dapat dimanfaatkan sebagai bahan biskuit MP-ASI adalah ikan patin dan kacang merah (Pangasius spp). Penelitian ini bertujuan menganalisis kontribusi MP-ASI biskuit bayi dengan subtitusi ikan patin dan kacang merah terhadap kecukupan protein dan vitamin A pada bayi. Jenis penelitian ini adalah eksperimental murni dan semu dengan menggunakan Rancangan Acak Kelompok (RAK) yang dilakukan dengan studi pendahuluan pengembangan formulasi biskuit fishebean dan nilai kandungan gizi di laboratorium
\end{abstract}


Teknologi Pangan Poltekkes Kemenkes Bengkulu. Populasi adalah bayi dan balita di Puskesmas Beringin Raya sebagai kelompok kasus dan Puskesmas Lempuing sebagai kelompok kontrol. Jumlah sampel sebanyak 30 orang, pengambilan sampel menggunakan metode Non Probability Sampling. Data responden dikumpulkan dengan kuisioner, form uji organoleptik, dan food recall asupan selama 3 hari. Data dianalisis dengan one way anova dan uji beda rata-rata dengan metode independen sample t-test. Hasil penelitian didapatkan ada perbedaan asupan protein dan vitamin A pada kelompok perlakuan (bayi yang diberi biscuit fishbean) dan kelompok kontrol (bayi yang diberi biscuit pabrikkan) dengan rerata 40.60 : 30.07. Terdapat perbedaan asupan protein dan vitamin A antara kelompok control dengan kelompok kasus yakni rata-rata kontribusi biscuit fishbean terhadap kecukupan protein bayi adalah 19,60 gram.

Kata Kunci : Biskuit FishBean, Protein, Vitamin A

\section{PENDAHULUAN}

Kurang energy protein (KEP) dan defisiensi vitamin A memiliki hubungan yang erat. KEP pada balita dapat menimbulkan defisiensi vitamin A karena rendahnya asupan protein biasanya diikuti oleh rendahnya asupan vitamin $\mathrm{A}$, selain itu dapat mengakibatkan terhambatnya absorbs, transportasi, dan konversi vitamin A. demikian juga defisiensi vitamin A yang ditimbulkan dapat menurunkan sistem kekebalan tubuh, sehingga dapat meningkatkan resiko penyakit infeksi yang dapat memperburuk kejadian KEP pada balita (Trahms, 2008).

Konsumsi makanan dalam jumlah dan kandungan gizi yang cukup sangat diperlukan untuk tumbuh kembang bayi dan balita. Sesudah bayi berusia enam bulan, kandungan gizi ASI tidak lagi mencukupi sementara kebutuhan energi bayi meningkat sebesar 24-30\% dibandingkan dengan kebutuhan saat usia
3-5 bulan ${ }^{1}$. Untuk memenuhi kebutuhan zat gizi yang meningkat, Makanan Pendamping ASI (MP-ASI) perlu diberikan pada bayi sesudah berusia 6 bulan. Zat gizi yang penting untuk dipenuhi pada masa bayi diantaranya protein dan vitamin A. Protein untuk bayi berperan dalam pertumbuhan dan pemeliharaan sel, sedangkan vitamin A berperan dalam fungsi sistem imun, melindungi integritas sel-sel epitel lapisan kulit, permukaan mata, bagian dalam mulut, serta saluran pencernaan dan pernafasan (Windayani, 2007).

Biskuit dapat dijadikan sebagai makanan tambahan untuk bayi dan balita. Tingkat konsumsi biscuit dari tahun 1998 sampai dengan tahun 2002 mengalami peningkatan yaitu dari 456,27 gram perkapita pertahun menjadi 576,19 gram perkapita pertahun dan diperkirakan akan terus mengalami peningkatan (Khosman, 2009). Salah satu bahan pangan lokal 
27 Jurnal Ilmu dan Teknologi Kesehatan, Vol 6 Nomor 1, September 2018, hlm : 25 - 37

sumber protein yang dapat dimanfaatkan sebagai bahan MP-ASI adalah ikan patin (Pangasius spp). Ikan patin merupakan ikan air tawar yang banyak dibudidayakan di Indonesia dengan harga yang relatif terjangkau. Kandungan protein pada ikan patin cukup tinggi yaitu sebesar 14,53\%. Bahan pangan yang kaya akan vitamin A juga perlu digunakan untuk memenuhi persyaratan kandungan vitamin A pada MP-ASI. Pemanfaatan kacang merah untuk memenuhi kebutuhan pangan di Indonesia sudah dilakukan masyarakat tetapi masih sangat terbatas penggunaanya. Kacang merah (Phaseolus vulgaris L,) memiliki kandungan protein cukup tinggi, yaitu antara $21-27 \%{ }^{6}$. Komposisi bahan yang kaya zat gizi serta metode pengolahan yang tepat diharapkan akan menghasilkan MP-ASI yang bergizi tinggi dan dapat diterima oleh konsumen. Penelitian ini bertujuan untuk menganalisis kontribusi MP-ASI biskuit bayi dengan subtitusi ikan patin dan kacang merah terhadap kecukupan protein dan vitamin A pada bayi.

\section{METODE PENELITIAN}

Penelitian ini merupakan penelitian eksperimental murni dan semu dengan menggunakan Rancangan Acak Kelompok (RAK) yang dilakukan dengan studi pendahuluan pengembangan formulasi biskuit fishebean dan nilai kandungan gizi di laboratorium Teknologi Pangan Poltekkes Kemenkes Bengkulu. Sampel dalam penelitian ini adalah bayi dengan usia 6-12 bulan yang berada di wilayah Puskesmas beringin raya sebagai kelompok kasus dan di wilayah puskesmas lempuing sebagai kelompok kasus yang berjumlah 15 orang. Untuk uji daya terima biscuit dilakukan terhadap panelis terlatih yaitu pada 30 mahasiswa tingkat 3 jurusan gizi poltekkes kemenkes Bengkulu. melalui uji organoleptik yang meliputi uji kesukaan terhadap warna, aroma, tekstur dan rasa formula biskuit fishebean, satu faktor untuk mengetahui perbedaan kandungan zat gizi, dan daya terima MPASI biskuit bayi pada berbagai variasi persentase substitusi tepung ikan patin (Pangasius spp) dan tepung kacang merah (Phaseolus vulgaris L).

Persentase substitusi tepung ikan patin dan tepung kacang merah ditentukan berdasarkan estimasi perhitungan total kandungan zat gizi bahan baku pembuatan biskuit dengan mempertimbangkan persyaratan kadar protein protein, energy, dan vitamin A pada makanan tambahan bayi menggunakan program Nutrisurvey for Windows 2005. Setiap perlakuan dilakukan 3 kali pengulangan dengan perbandingan persentase tepung ikan ikan dan tepung kacang erah yakni 15:10, 15:15, 20:10. Untuk pengukuran daya 
terima dilakukan sebanyak 1 kali pengujian.

Penelitian dilakukan pada bulan September-November 2014. Untuk mengetahui Kontribusi MP-ASI biskuit bayi dengan subtitusi ikan patin dan kacang merah terhadap kecukupan protein dan vitamin A pada bayi diperoleh dengan cara menggunakan metode food recall selama 3×24 jam kemudian dianalisa dengan menggunakna program nutri survey. Untuk mengetahui daya terima konsumen ditentukan melalui uji organoleptik dengan menggunakan skala Hedonik yang dilakukan pada mahasiswa gizi tingkat III sebagai panelis terlatih (Soekarto, 1981).

Analisis data menggunakan program SPSS 16.0 for Windows. Pengaruh substitusi ikan patin dan kacang merah pada biskuit bayi diuji dengan One Way Anova dengan derajat kepercayaan 95\% yang dilanjutkan dengan Posthoc Test Tukey untuk mengetahui beda nyata kandungan protein, energi dan vitamin A antar perlakuan. Data penerimaan biskuit bayi menggunakan uji Friedman dan uji lanjut Wilcoxon. Analis selanjutnya adalah Anlisis $t$ test dependen untuk mengetahui asupan zat gizi makro dan vitamin $\mathrm{A}$.

\section{HASIL DAN PEMBAHASAN}

Dari hasil penelitian ini dapat dilihat bahwa kandungan zat gizi biscuit fishebean yang tinggi terjadi pada perlakuan P1, yang berarti semakin banyak penambahan tepung ikan patin dan tepung kacang merah maka semakin meningkat beberapa nilai zat gizinya, terutama nilai zat gizi makro nya dan vitamin A. Dapat di lihat pada Tabel 1 berikut ini.

Tabel 1. Komposisi Zat Gizi biscuit fishebean PenambahanTepung Ikan patin dan tepung kacang merah dalam 500 gram

\begin{tabular}{cccc}
\hline \multirow{2}{*}{ Zat Gizi } & \multicolumn{2}{c}{ Penambahan Tepung Ikan patin \& tepung kacang merah } \\
& $\mathbf{P 1}$ & $\mathbf{P 2}$ & $\mathbf{P 3}$ \\
\hline Energi & $2429.1 \mathrm{kkal}$ & $2596.6 \mathrm{kkal}$ & $2645.6 \mathrm{kkal}$ \\
Protein & $79 \mathrm{gr}$ & $90.5 \mathrm{gr}$ & $99.5 \mathrm{gr}$ \\
Lemak & $123.9 \mathrm{gr}$ & $124.5 \mathrm{gr}$ & $125.7 \mathrm{gr}$ \\
Karbohidrat & $252.1 \mathrm{gr}$ & $281.9 \mathrm{gr}$ & $281.9 \mathrm{gr}$ \\
Vitamin A & $594 \mathrm{IU}$ & $594 \mathrm{IU}$ & $608 \mathrm{IU}$ \\
\hline
\end{tabular}

Pada tabel diatas dapat diketahui bahwa nilai gizi energy, protein, lemak, karbohidrat dan vitamin A tertinggi terdapat pada biscuit dengan perlakuan penambahan tepung ikan patin dan tepung kacang merah dengan perbandingan persentase $20: 10$. Pengaruh variasi konsentrasi tepung ikan patin dan tepung 
kacang merah terhadap mutu organoleptik (warna) biscuit fishebean didapatkan hasil bahwa perlakuan 1 memiliki tingkat kesukaan tertinggi (Gambar 2). Dari hasil uji kruskal wallis didapatkan hasil bahwa panelis tidak bisa membedakan warna untuk ketiga jenis biscuit fishebean dengan variasi penambahan tepung ikan patin dan tepung kacang merah yang berbeda dan dapat diartikan bahwa semakin banyak penambahan tepung ikan patin dan tepung kacang merah maka semakin tingkat kesukaan panelis terhadap mutu organoleptik (warna) biscuit fishebean. Untuk peniliaan terhadap mutu organoleptik rasa, diketahui bahwa sebanyak 20 orang panelis memberi penilaian suka (skor 6) untuk rasa biscuit fishebean pada perlakuan P1. Sedangkan untuk pengaruh variasi konsentrasi tepung ikan patin dan tepung kacang merah terhadap tekstur biskuit diketahui bahwa sebanyak 14 orang panelis memberi penilaian suka (skor 6) untuk rasa biscuit fishebean pada perlakuan P1.

\section{Karakteristik Subjek Penelitian}

Berdasarkan tabel dibawah, dapat diketahui bahwa rata-rata asupan zat gizi energy, protein, lemak, karbohidrat dan vitamin A pada kelompok kasus lebih tinggi diabndingkan dengan kelompok control. Hasil ini didapatkan dari hasil recall asupan selama 3 hari, dengan pemberian biscuit fish bean@80 gram.

Tabel 2. Distribusi Frekuensi Karakteristik Subjek Penelitian

\begin{tabular}{|c|c|c|c|c|c|}
\hline \multirow{2}{*}{ Karakteristik } & \multicolumn{2}{|c|}{ Perlakuan } & \multicolumn{2}{|c|}{ Kontrol } & \multirow[t]{2}{*}{ Tota } \\
\hline & $\mathbf{N}$ & $\%$ & $\mathbf{N}$ & $\%$ & \\
\hline \multicolumn{6}{|l|}{ Usia Anak } \\
\hline $7-12$ bulan & 12 & 80 & 14 & 93,3 & 26 \\
\hline 13-18 bulan & 3 & 20 & 1 & 6,7 & 4 \\
\hline \multicolumn{6}{|l|}{ Pendidikan Ibu } \\
\hline SD & 1 & 7 & 0 & 0 & 1 \\
\hline SMP & 4 & 26,7 & 5 & 33,3 & 9 \\
\hline SMA & 10 & 66,3 & 9 & 60 & 19 \\
\hline Diploma 3 & 0 & 0 & 1 & 6,7 & 1 \\
\hline
\end{tabular}

Tabel 3. Asupan Energi, Protein, Lemak dan Karbohidrat

\begin{tabular}{lcccccc}
\hline \multirow{2}{*}{ Variable } & \multicolumn{3}{c}{ Kasus } & \multicolumn{3}{c}{ Kontrol } \\
\cline { 2 - 7 } & Mean & SD & N & Mean & SD & N \\
\hline Energi & 611.07 & 179.11 & 15 & 563.27 & 131.98 & 15 \\
\hline Protein & 19.60 & 9.11 & 15 & 19.2 & 8.93 & 15 \\
\hline Lemak & 10.20 & 9.37 & 15 & 14.93 & 8.62 & 15 \\
\hline KH & 91.73 & 43.21 & 15 & 83.00 & 25.49 & 15 \\
\hline Vit A & 40.60 & 6.72 & 15 & 30.07 & 7.56 & 15 \\
\hline
\end{tabular}


2. Analisis Bivariat

Analisis bivariat digunakan untuk mengetahui adakah perbedaan asupan zat gizi makro dan vitamin A pada kelompok yang mendapat perlakuan dengan kelompok control dengan menggunakan uji T-test independen.

Tabel 4. Perbedaan Asupan Zat Gizi Makro dan Vitamin A Kelompok Kasus dan Kelompok Perlakuan

\begin{tabular}{lccccc}
\hline \multicolumn{1}{c}{ Variabel } & Mean & SD & SE & P-Value & N \\
\hline $\begin{array}{l}\text { Energi } \\
\text { Perlakuan } \\
\text { Kontrol }\end{array}$ & 4,78 & 250,19 & 64,60 & 0,472 & 15 \\
\hline $\begin{array}{l}\text { Protein } \\
\text { Perlakuan } \\
\text { Kontrol }\end{array}$ & 0,4 & 11,07 & 2,86 & 0,001 & 15 \\
\hline $\begin{array}{l}\text { Lemak } \\
\text { Perlakuan } \\
\text { Kontrol }\end{array}$ & 4,73 & 14,43 & 3,727 & 0,225 & 15 \\
\hline $\begin{array}{l}\text { Karbohidrat } \\
\text { Perlakuan }\end{array}$ & 8,73 & 52,25 & 13,493 & 0,528 & 15 \\
$\begin{array}{l}\text { Kontrol } \\
\text { Vitamin A } \\
\begin{array}{l}\text { Perlakuan } \\
\text { Kontrol }\end{array}\end{array}$ & 1,05 & 7,909 & 2,0421 & 0,000 & 15 \\
\hline
\end{tabular}

3. Kandungan zat gizi energi, karbohidrat, lemak, protein dan vitamin A biskuit bayi dengan subtitusi ikan patin dan kacang merah

Kekurangan gizi merupakan maslalah utama kesehatan masyarkat di negara berkembang dan merupakan akar factor. Penelitian di Ethiopia menunjukkan factor penyebab severe malnutrition berhubungan dengan pemberian makanan yang kurang memadai, pemberian ASI yang tidak ekslusif 6 bulan, dan terlambat mulai memberikan makanan pendamping. Penelitian yang juga dilakukan di Ethiopia bagi penderita SAM dalam program darurat yang dilakukan secara rawat jalan yaitu dengan pemberian paket makanan terapi siap makan ready to use therapeutic food(RUTF)bentuk pasta. Hasil penelitian menunjukkan $85 \%$ anak dapat pulih, $4 \%$ meninggal, $6 \%$ dirujuk untuk dirawat lebih lanjut, sisanya drop out (18\%) (Colin, 2006).

Pada anak usia $6-12$ bulan bayi mulai bisa diberi makanan pendamping ASI, karena pada usia itu bayi sudah mempunyai refleks mengunyah dengan pencernaan yang lebih kuat. Dalam pemberian 
makanan bayi perlu diperhatikan jenis dan julah bahan yang digunakan, cara pembuatannya frekuensi dan waktu pemberian. Pemberian MPASI yang terlalu dini berakibat gizi lebih juga bisa menimbulkan beban zat terlarut sehingga dapat menimbulkan hyperosmolarity. Praktik pemberian makanan yang buruk meliputi kualitas dan kuantitas serta Preferensi ibu dalam memilih MP ASI juga merupakan factor dominan yang mempengaruhi pertumbuhan fisik dan perkembangan mental ${ }^{8,9}$. Komposisi zat gizi MP ASI mempengaruhi asupan makanan dan pertumbuhan. Penelitian Suhartono menunjukkan tidak ada perbedaan yang signifikan pada anak yang mendapat intervensi PMT jika komposisi zat gizi tidak menjadi perhatian,anak tidak mendapatkan MP ASI yang tergolong baik secara kualitatif dan cukup secara frekuensi. Penelitian yang dilakukan di UK mengungkapkan keberhasilan program rawat jalan hingga $85 \%$ pada kasus SAM dengan pemberian RUTF (Colin, 2002).

Nilai kandungan protein tepung ikan patin yang tinggi dan Kacang merah mampu memberikan protein yang setara dengan daging, ada terdapat 1 Asam Amino Essensial pada kacang merah, sehingga mampu membantu melengkapi kekurangan komponen protein (Asam amino) pada kacang merah. Dalam 100 gr kacang merah kering, mampu menyumbangkan 4 gr serat, yang terdiri atas campuran serat larut dan serat tak larut dengan Indeks Glikemik (IG) atau angka untuk mengukur efek makan terhadap konsentrasi gula darah yang rendah, yaitu 22-32. Di dalam usus, kacang merah dicerna secara lambat, sehingga gula darah meningkat lebih lama dan insulin sebagai hormon pengatur metabolisme karbohidrat yang dibutuhkan lebih sedikit dibandingkan dengan kebanyakan makanan yang kaya karbohidrat.

Komposisi Zat Gizi biscuit fishebean PenambahanTepung Ikan patin dan tepung kacang merah dalam 100 gram memiliki nilai gizi lebih baik yaitu energy 485.82 kkal, protein 15.8 gram, lemak 24.78 gram, 46 gram dan vitamin A 594 IU. Jika dibandingkan dengan kandungan zat gizi MP ASI menurut permenkes nomor 224/menkes/SK/II/2007 (DBGKAI, 2011). Hal ini menunjukkan bahwa biscuit fishebean Sebagai Alternatif Makanan Tambahan Bagi bayi menunjukkan nilai ekonomi pada biscuit fishebean, biskuit dengan komposisi penambahan tepung ikan patin dan tepung kacang merah yang berbeda sebagai alternatif makanan tambahan bagi anak sekolah dengan Unit Cost biscuit fishebean tiap porsi berkisar antara Rp1.500, - hingga Rp 1.750,- dan biaya tersebut masih memenuhi unit cost 
PMT yaitu Rp 2.250,- untuk kawasan Indonesia Barat.

4. Mutu daya terima biskuit bayi dengan subtitusi ikan patin dan kacang merah Mutu organoleptik (warna) biscuit fishebean tidak dipengaruhi oleh penambahan variasi konsentrasi tepung ikan patin dan tepung kacang merah. Hal ini dikarenakan intensitas warna yang hampir sama antara produk. Warna yang hampir sama untuk ketiga biscuit fishebean tersebut juga dipengaruhi oleh kandungan protein yang tinggi dari tepung ikan patin dan tepung kacang merah berperan dalam reaksi Maillard dan adanya proses pemanasan akan memberikan warna coklat pada saat biscuit fishebean di open. Menurut Winarno, reaksi Maillard merupakan reaksi antara karbohidrat, khususnya gula preduksi dengan $\mathrm{NH}_{2}$ dari protein yang menghasilkan senyawa hidroksimetilfurfural yang kemudian berlanjut menjadi furfural. Furfural yang terbentuk kemudian membentuk senyawa melanoidin yang berwarna coklat. Melanoidin inilah yang memberikan warna coklat pada biscuit fishebean. Reaksi Maillard menurut Borgstrom (2000) dalam Suwandi, akan semakin cepat terjadi apabila suhu diatas $100^{\circ} \mathrm{C}$. Adapun faktor yang mempengaruhi warna biscuit fishebean yang dihasilkan yaitu suhu pemanggangan. Pada pembuatan, campuran yang digunakan ukurannya sama dan lama proses pembakaran/pemanggangan juga sama, sehingga hasil warna antara 3 produk biscuit fishebean dengan penambahan tepung ikan sidat tersebut relatif sama (Winarno, 2004).

Berdasarkan penelitian diketahui bahwa mutu organoleptik (rasa) biscuit fishebean tidak dipengaruhi oleh penambahan variasi konsentrasi tepung ikan patin dan tepung kacang merah. Hal ini dikarenakan rasa biscuit fishebean yang hampir sama pada perlakuan P1, P2, dan P3. biscuit fishebean mengandung banyak protein yang dapat mempengaruhi rasa dari biscuit fishebean. Menurut Winarno, (protein mengandung beberapa asam amino diantaranya adalah asam glutamat. Asam glutamat sangat penting perannya dalam pengolahan makanan, karena dapat menimbulkan rasa yang lezat dan dapat meningkatkan cita rasa yang diinginkan sambil mengurangai rasa yang tidak diinginkan (Winarno, 2004).

Berdasarkan penelitian diketahui bahwa mutu oragnoleptik (tekstur) biscuit fishebean tidak dipengaruhi oleh penambahan variasi konsentrasi tepung ikan patin dan tepung kacang merah. Hal 
ini dikarenakan biscuit fishebean tidak menggunakan santan dan hanya sedikit telur. Menurut Winarno, penambahan lemak (santan dan telur) dimaksudkan untuk menambah kalori serta memperbaiki tekstur dan cita rasa makanan. Air yang terkandung dalam bahan makanan dapat mempengaruhi tekstur dan cita rasa makanan. Semakin sedikit air dalam bahan makanan, maka tekstur bahan makanan semakin keras. Didalam pembuatan biscuit fishebean tidak menggunakan air tetapi menggunakan sedikit telur (Winarno, 2004).

Penambahan tepung ikan patin dan tepung kacang merah pada biscuit fishebean berpengaruh terhadap aroma. Hal ini dikarenakan ikan yang merupakan sumber protein. Di samping timbulnya aroma terbentuk juga gula selama pemanggangan. Bertambahnya senyawa mudah menguap pada saat pemasakan sangat erat hubungannya dengan pembentukan aroma pada biscuit fishbean.

5. Kontribusi MP-ASI biskuit bayi dengan subtitusi ikan patin dan kacang merah terhadap kecukupan protein pada bayi

Hasil penelitian menunjukkan kontribusi MP-ASI biskuit bayi dengan subtitusi ikan patin dan kacang merah terhadap kecukupan protein pada bayi rata-rata pada kelomok kasus 19.60 gram sedangkan pada kelompok kontrol lebih rendah yakni 19.20 gram.

Kandungan protein pada ikan patin cukup tinggi yaitu sebesar 14,53\%. Ikan Patin memiliki manfaat sebagai sumber penyediaan protein hewani dengan kandungan protein tinggi dibandingkan ikan air tawar lainnya, seperti ikan lele dengan kandungan protein $10.5 \%$. Kandungan protein ikan patin pada 159 gr fillet ikan patin adalah sebesar $24,7 \mathrm{gr}$, kandungan gizi lainnya adalah lemak $1,03 \%$, abu $0,74 \%$, dan air $82,22 \%$. Kacang merah memiliki Serat larut berfungsi menurunkan konsentrasi kolesterol dan gula darah. Serat larut mengalami proses fermentasi dalam usus besar, kemudian menghasilkan asam-asam lemak rantai pendek, yang dapat menghambat sintesis kolesterol hati. Kacang merah hampir bebas lemak jenuh dan kolesterol, dan memiliki Indeks Glikemik (IG) atau angka untuk mengukur efek makan terhadap konsentrasi gula darah yang rendah, yaitu 22-32. Di dalam usus, kacang merah dicerna secara lambat, sehingga gula darah meningkat lebih lama dan insulin sebagai hormon pengatur metabolisme karbohidrat yang dibutuhkan lebih sedikit dibandingkan dengan 
kebanyakan makanan yang kaya karbohidrat (Suhartono, 2008).

Salah satu upaya yang dilakukan pemerintah adalah pemberian makanan tambahan secara gratis kepada bayi dan anak usia 6-24 bulan berupa makanan pendamping yang masih diberikan berupa MP ASI bubuk Instan biscuit. Penelitian Adiyasa mengenai evaluasi program pemberian MP-ASI bubuk instan dan biscuit di kota mataram,kabupaten Lombok barat, Lombok timur dan Bengkulu utara menunjukkan bahwa Dalam pelaksanaan kegiatan pemberian MP ASI pabrikan, menimbulkan beberapa masalah antara lain: tidak tepat sasaran, masalah dalam penyimpanan, ada beberapa bayi menolak karena alasan kebiasaan (Adiyasa, 2010).

\section{Kontribusi MP-ASI biskuit bayi} dengan subtitusi ikan patin dan kacang merah terhadap kecukupan vitamin A pada bayi

Bayi merupakan golongan penduduk yang berada pada masa pertumbuhan yang cepat dan aktif secara fisik, dengan tahapan motorik yang tampak jelas sehingga membutuhkan lebih banyak energy. Penelitian Mery menunjukkan bahwa anak yang memiliki status gizi kurang/gizi buruk disebabkan oleh makanan yng kurang baik yang merupakan factor protektif yaitu jenis maupun kualitasnnya. Kecenderungan tersebut berkoreksi juga dengan MP ASI local untuk balita yng seharusnya terdiri dari zat gizi yang mencukupi, aman bagi kesehatan dan harganya terjangkau oleh keluarga miskin (Husni, 2009). Salah satu upaya yang dipilih menanggulangi masalah tersebut adalah pemberian MPASI yang dapat memenuhi dan peningkatan zat gizi biskuit dengan subsitusi ikan patin dan tepung kacang merah memiliki kandungan vitamin A yang cukup tinggi. Dari hasil penelitian Kontribusi MP-ASI biskuit bayi dengan subtitusi ikan patin dan kacang merah terhadap kecukupan vitamin A pada bayi lebih tinggi pada kelompok balita yang diberikan biskuit Fishebean yakni 40.60 IU sedangkan pada kelompok control rata-rata asupan vitamin A 30.07 IU.

Kacang merah kering merupakan sumber protein nabati, karbohidrat kompleks, serat, vitamin A, folasin, tiamin, kalsium, fosfor dan zat besi. produk MP-ASI seringkali ditambahkan berbagai jenis vitamin dan mineral antara lain Vitamin A, D, E, C, B1, B2, B6, folat, B12, mineral $\mathrm{Ca}, \mathrm{Fe}$, iodin dan $\mathrm{Zn}^{16}$. Produk MP-ASI seringkali ditambahkan berbagai jenis vitamin dan mineral antara lain Vitamin A, D, E, C, B1, B2, B6, folat, B12, mineral Ca, Fe, iodin dan Zn (Purwadani, 2008). 
35 Jurnal Ilmu dan Teknologi Kesehatan, Vol 6 Nomor 1, September 2018, hlm : 25 - 37

Pemberian MPASI yang cukup, baik kualitas maupun kuantitas merupakan dasar dari pertumbuhan dan perkembangan fisik serta kecerdasan bayi selanjutnya. Peran keluarga terutama ibu dalam mengasuh akan menentukan tumbuh kembang anak. Perilaku ibu dalam pemberian MPASI, memberikan makanan bergizi dan mengontrol besar porsi yang dihabiskan akan meningkatkan status gizi anak (Husnaeni, 2009).

7. Perbedaan asupan zat gizi makro dan vitamin A pada kelompok perlakuan dan control

Dari hasil penelitian sebagian besar usia bayi yang mendapat perlakuan dalam penelitian ini adalah 7-12 bulan yakni $80 \%$, dengan pendidikan ibu $66,3 \%$ nya adalah SMA. Sedangkan pada kelompok kasus, 93,3\% bayi berusia 7-12 bulan dengan pendidikan ibu $60 \%$ nya adalah SMA. Karakteristik responden merupakan salah satu factor yang dapat mempengaruhi ibu dalam memberikan MPASI. Beberapa penelitian menunjukkan Pendidikan ibu tentang MPASI sangat berpengaruh, semakin tinggi tingkat pendidikan ibu. Penelitian Manalu,2010 menunjukkan bahwa anak yan memiliki status gizi kurang/ buruk disebabkan oleh MPASI yang kurang baik, jenis dan kualitasnya. Kekurangan tersebut dipengaruhi oleh rendahnya pendidikan dan pengetahuan ibu dan keluarga. Penelitian Webb,Horton 2005, menunjukkan bahwa orang tua yang memiliki kemampuan kognitif rendah anaknya juga cenderung mengalami gizi kurang dan kemampuan kognitif yang rendah pula (Webb, 2005).

Beradasarkan hasil analisis t-test dependen, menunjukan bahwa tidak ada perbedaan asupan Energi, Lemak, Karbohidrat. Dan ada perbedaan asupan protein dan vitamin A pada kelompok perlakuan dan kelompok control. Untuk asupan protein rata-rata pada kelomok kasus 19.60 gram sedangkan pada kelompok kontrol lebih rendah yakni 19.2 gram. sedangkan untuk asupan vitamin A pada kelompok kasus yakni 40.60 sedangkan pada kelompok control lebih rendah yakni hanya 30.07 IU.

Hal ini didukung penelitian Adiyasa 2010, Program pemberian MP ASI bubuk instan dan biscuit sebagian besar $(95,6 \%)$ dapat meningkatkan asupan dan berat badan balita. Penelitian Kartika,2000 bayi yang berusia 5 bulan akan mengalami peningkatan berat badan 2 kali berat badan dan menjadi 3 kali berat badan lahir pada usia 12 bulan, sehingga usia 6-11 bulan pertumbuhan bayi sangat pesat (Kartika, 2000). 


\section{SIMPULAN}

Terdapat perbedaan asupan protein dan vitamin A antara kelompok kontrol dengan kelompok kasus yakni rata-rata kontribusi biscuit fishbean terhadap kecukupan protein bayi adalah 19,60 gram.

\section{DAFTAR RUJUKAN}

Trahms CM, Mc Kean KN. Nutrition During Infancy. In: Mahan LK, Escott-Stump S. Krause's Food and Nutrition Theraphy 12th ed. Canada: Elsevier. 2008.

Widayani S. 2007. Efikasi dan Preferensi Biskuit yang di Fortifikasi Vitamin A dan Zat Besi (Fe) dan Kaitannya dengan Konsumsi, Status Gizi dan Respon Immune Anak Balita (Disertasi). IPB: Bogor

Ali Khomsan. 2004. Pangan dan Gizi untuk Kesehatan.Ed.I: Raja Grafindo Persada. Jakarta

Winarno, F. G., 2004. Kimia Pangan dan Gizi. Gramedia Pustaka Utama, Jakarta.

Soekarto, Soewarno T. Penilaian Organoleptik, untuk Industri Pangan dan Hasil Pertanian. Bogor: PUSBANGTEPA / Food Technology Development Center, Institut Pertanian Bogor. 1981

Hesti Purwandari, Endy.P.Prawirohartono, Sri Hartati, 2008, Usia penyapihan dan hubungannnya dengan intelegensi pada siswa TK, Jurnal gizi Klinik Indonesia volume 5 nomor 1,2008
Chandra, RK. 1997. Nutrition and Immune System: An Introduction. Am. J. Clin Nutr: 4505-4635

Dinas Kelautan dan Perikanan, 2011. Konsumsi Ikan Bengkulu Masih Rendah. Diaskes dari http:///E:/ikan/Konsumsi/Ikan_Be ngkuluMasih/Rendah Indonesian Sumatra.htm, 02 November 2012.

Ditjen Bina Gizi dan Kesehatan Ibu dan Anak. 2011. Panduan Penyelenggaraan Pemberian Makanan Tambahan Bagi Balita Gizi Kurang. Kemenkes RI. Jakarta

Husni, Agung Riyadi, 2009, Hubungan Pola Asuh Keluarga Dan Pola Pemberian Makan dengan Status Berat Badan Balita di Puskesmas Pasar Ikan Kota Bengkulu, jurnal Media Kesehatan volume 2 no 03 juni 2009

Kartika V. 2002. Faktor -Faktor yang Mempengaruhi Kemampuan Motorik Anak Usia 12-18 bulan di Keluarga Miskin dan tidak Miskin, Bogor, Puslitbang Gizi; Penelitian Gizi dan Makanan vo.5

Collin S, Sadler K. 2002. Outpatient care for severe malnourished children in emergency relief progammes; a retrospective cojort study. Lancet; 360;1824-30.

Collin S, Sadler K, uerrero S, Myatt M, SaboyaM, Walsh A.2006. Key issues in the success of community-based management of severe malnutrition. Food and Nutrition Bulletin.27(3) (supplement)

Adiyasa I Nyoman, Hadi H,Gunawan Alit I made. 2010. Evaluasi program pemberian MP-ASI bubuk Instan 
dan Biskuit diKota Mataram, kabupaten Lombok Barat, Lombok Timur dan Bengkulu Utara tahun 2007. Jurnal Gizi Klinik Indonesia 6(3);145-155.

Webb KE, Harton NJ, \& Katz DL. 2005. Parenteral IQ and cognitive development of malnourished Indonesia children, European Journal of Clinical Nutritiun, 59, 618-620

Husaini,MA,Karyadi L, Husaini YK, Karyadi D, \& Pollit E,2000. Developmental effects of Shortterm Suplementary Feeding in Nutritionally at risk Indonesian Infant. Am.J.Clin.Nutr,45.

Menteri Kesehatan Republik Indonesia. Keputusan Menteri Kesehatan Republik Indonesia Nomor: 224/Menkes/SK/II/2007 Tentang Spesifikasi Teknis Makanan Pendamping Air Susu Ibu (MPASI). Jakarta. 2007

LIPI. Angka Kecukupan Gizi yang Dianjurkan. Widyakarya Nasional Pangan dan Gizi. 2004
I Wayan Sweca Yasa, Nazaruddin dan Satrijo Saloko. 2009. Keefektifan Berbagai Jenis Tepung Kecambah Kacang Meningkatkan Mutu Makanan Sapihan Tradisional. Jurusan Teknologi Pertanian Fakultas Pertanian Universitas Mataram

Riwan, 2006. Sifat-sifat Organoleptik. Diakses dari http://tekhnologihasil-pertanian.blogspot.com.

Maret 2012.

Yuni Ramawati,2011. Daya Terima, Nilai Kandungan Gizi, dan Nilai Ekonomi Biskuit Morin (Moringa oleifera) Sebagai Alternatif Makanan Tambahan Bagi Anak Sekolah, Kesehatan Masyarakat, Universitas Muhamadiyah Malang

FAO/WHO. 1994. Guidelines on Formulated Suplementary Food for Older Infants and Young Children. FAO/WHO: Roma

World Health Organization. Complementary Feeding: Family Foods for Breastfed Children. Department of Nutrition and Development. Geneva: WHO. 2000 